\title{
Hematopoietic, Electrolyte and Glycemic Activities of Whitfieldia lateritia Leaf Decoction and Vitali Supplement on Phenylhydrazine-induced Anemic Cockerels
}

\author{
U.C. Okorie ${ }^{1}$, J.A. Onu², S.C. Ogunwa ${ }^{1}$, G. Otuchristian², C.C. Njemanze', \\ C.F. Ezeanya ${ }^{1}$, D.O. $\lg ^{1} e^{1}$
}

10.18805/ajdfr.DR-198

\begin{abstract}
Background: Hematological indices are important factors for the evaluations health status. Plant materials are often used as feed supplements by farmers to combat animal health challenges and have been a source of relief for the management of anemia in developing countries; for example, Whitfieldia lateritia is used in folklore medicine as anti-anemic agent. The hematopoietic, electrolyte and glycemic activities of Whitfieldia lateritia leaf decoction and vitali supplement on phenylhydrazine (PHZ)-induced anemic cockerels were investigated.

Methods: A total of 60 cockerels were purchased and allowed to acclimatize for two weeks. Thereafter, classified into 12 groups (designated as T1....T12) of 5 cockerels each, where T2, T3 and T4 received 100, 200 and $400 \mathrm{mg} / \mathrm{kg}$ body weight $W$. lateritia leaf decoction, respectively. Anemia was induced in groups, T5.....T12 by the administration of $10 \mathrm{mg} / \mathrm{kg}$ body weight PHZ for 3 consecutive days; thereafter, T5, T6 and T7 received 100, 200 and $400 \mathrm{mg} / \mathrm{kg}$ body weight $W$. lateritia leaf decoction, respectively; T8, T9 and T10 were administered 100, 200 and $400 \mathrm{mg} / \mathrm{kg}$ body weight vitali supplement, respectively; while T1, T11 and T12 were the normal control, negative control and baseline control, respectively. The treatment lasted for 30 days.

Conclusion: Saponin, flavonoids, tannins, cardiac glycosides and steroids were detected. The glucose concentrations and hematological indices of the cockerels treated with the $W$. lateritia leaf decoction and the vitali supplement compared with the normal control. The $W$. lateritia leaf decoction displayed positive hematological, electrolyte and glycemic activities, thus may justify the use in maintaining animal health.
\end{abstract}

Key words: Anemia, Blood, Glucose, Hematology, Phenylhydrazine.

\section{INTRODUCTION}

Anemia is a disease condition resulting from an insufficiency of the total amount of red blood cells and or hemoglobin in the blood (Janz et al., 2013). The reduction in any or all of the blood parameters may decrease the oxygen-carrying capacity of the blood, thus, decreasing the oxygenation of the body which triggers perturbation of metabolic activities including electrolyte and glycemic homeostasis. Relationships exist between anemia and serum glycemic index (Awofisoye et al., 2019) including electrolytes and hyperglycemia exists (Khan et al., 2019). Anemia remains a major cause of mortality and morbidity in developing countries where nutritional disorder and infection have been identified as the major cause (Kayode and Adeolu 2012); feed supplementation can improve anemia in animals (Parashuramulu et al., 2015; Prity et al., 2019). Hematological indices are important factors for the evaluations health status (Boon et al., 2019). Medicinal plants have been a source of relief for the management of anemia in developing countries (Upasana et al., 2018); for example, Whitfieldia lateritia is used in folklore medicine as anti-anemia (Okorie et al. 2020; Njoku et al., 2015). W. lateritia is a flowering plant that belongs to the family of Acanthaceae (D'Incalcie, 2005). It is known as "ogwu obara" in lgbo, "ogu neje" in Yoruba and "magani" in Hausa (Aja et al.,
'Department of Chemistry/Biochemistry/Molecular Biology, AlexEkwueme Federal University Ndufu Alike, Abakaliki, Ebonyi State, Nigeria. ${ }^{2}$ Animal Science Department, Federal College of Agriculture Ishiagu, Ebonyi State, Nigeria.

${ }^{3}$ Science Laboratory Technology Department, Akanu Ibiam Federal Polytechnic, Uwanna, Ebonyi State, Nigeria.

Corresponding Author: U.C. Okorie, Department of Chemistry/ Biochemistry/Molecular Biology, Alex-Ekwueme Federal University Ndufu Alike, Abakaliki, Ebonyi State, Nigeria.

Email: uchechukwuc2002@yahoo.com

How to cite this article: Okorie, U.C., Onu, J.A., Ogunwa, S.C., Otuchristian, G., Njemanze, C.C., Ezeanya, C.F. and Igwe, D.O. (2021). Hematopoietic, Electrolyte and Glycemic Activities of Whitfieldia lateritia leaf Decoction and Vitali Supplement on Phenylhydrazine-induced Anemic Cockerels. Asian Journal of Dairy and Food Research. 40(3): 231-238. DOI: 10.18805/ajdfr.DR-198.

Submitted: 14-09-2020 Accepted:29-06-2021 Online: 02-08-2021

2016). Njoku et al., (2015) reported the use of Whitfieldia lateritia leaves for the treatment of anemia in rural communities in the South-Eastern Nigeria. Plants are the cheapest and readily available sources of medicinal agents in developing countries threatened by hidden hunger and increasing threat to survival due to population growth, food insecurity and economic crisis (Okorie et al. 2020; 
Njoku et al., 2015). W. lateritia leaves decoction is added to poultry drinking by some poultry farmers, claiming that it improves the poultry performances. These claims require scientific documentation since its use as animal feed supplement necessary because of the availability and affordability. Again poultry meat consumption is common in rural areas (Rajkumar et al., 2021). This study investigated the hematopoietic, electrolyte and glycemic activities of Whitfieldia lateritia leaf decoction and vitali supplement on phenylhydrazine-induced anemia in cockerels.

\section{MATERIALS AND METHODS Collection of $W$. lateritia leaves}

The fresh leaves of $W$. lateritia were collected from a forest in Ishiagu, Ebonyi State, Nigeria on September, 2019. The plant was identified by a taxonomist from the University of Port Harcourt and some leaves were deposited at their herbarium.

\section{Preparation of $W$. lateritia leaf decoction}

The fresh leaves of $W$. lateritia were collected, destalked, weighed and washed under running tap water. $30.8 \mathrm{~g}$ of the leaves were washed and then boiled with $300 \mathrm{ml}$ of distilled water at a temperature of $70^{\circ} \mathrm{C}$ for 15 minutes to extract the active ingredients of the plant in the form of decoction. Thereafter, the decoction extract was decanted into a sterilized container and stored in a refrigerator and later used for the biochemical studies.

$$
\% \text { Yield }=\frac{\begin{array}{l}
\text { Weight of beaker }+ \text { extract }- \\
\text { Weight of empty beaker }
\end{array}}{\text { Initial weight of sample beaker }} \times 100
$$

\section{Phytochemical screening}

The phytochemical screening for the presence of steroids, tannins, saponins, alkaloids, cardiac glycoside and flavonoids were carried out on the leaf extract of $W$. lateritia.

\section{Test for the presence of tannins}

This was carried out using Harbone method (1973). $1 \mathrm{ml}$ of crude extract of the sample was collected using a syringe and dispensed into the test tube. Then $1 \mathrm{ml}$ of $3 \%$ ferric chloride $\left(\mathrm{FeCl}_{3}\right)$ was added to the test tube. A dirty green precipitate was observed which showed the presence of tannins.

\section{Test for the presence of saponins by frohing test}

This was carried out by the method of Harborne (1973). $2 \mathrm{ml}$ of the extract was diluted with $5 \mathrm{ml}$ of distilled water in a test tube. The mixture was stirred vigorously for about 5 minutes and was allowed to stand for 30 minutes. Frothing which persisted for this duration indicated the presence of saponins.

\section{Test for presence of alkaloids}

This was carried out by the method of Trease and Evans (1989). $2 \mathrm{ml}$ of the extract was collected using a syringe and was dispensed into a test tube, the test tube was heated for 2 minutes and $5 \mathrm{mls}$ of $\mathrm{HCl}$ was added and heated again and allowed to cool. The mixture was divided into $A$ and $B$. To A, 2 drops of Meyer's reagent was added and a white precipitate was observed which showed the presence of Alkaloids. To B, 2 drops of Dragendroff's reagent was added and the formation of red precipitate was observed which confirmed the presence of alkaloids.

\section{Test for the presence of flavonoids}

This was carried out by the method of Harborne (1973). 5 $\mathrm{ml}$ of the extract was collected using a syringe and was dispensed into a test tube. Exactly $10 \mathrm{ml}$ of distilled water, 5 mls of dilute ammonium hydroxide $\left(\mathrm{NH}_{4} \mathrm{OH}\right)$ and few drops of $\mathrm{H}_{2} \mathrm{SO}_{4}$ were added in the test tube. A yellow colouration was observed which showed the presence of flavonoids.

\section{Test for the presence of cardiac glycoside}

This was carried out by the method of Harborne (1973). 2 $\mathrm{mls}$ of the extract was collected into a test tube and $5 \mathrm{ml}$ of glacial acetic acid was added and then $2 \mathrm{mls}$ of $\mathrm{FeCl}_{3}$ and 2 mls of concentrated ferric acid were added. A brown ring formation observed at the interphase of the mixture indicated the presence of deoxy sugar characteristics of cardiac glycosides.

\section{Test for steroids}

$2.0 \mathrm{ml}$ of chloroform and concentrated $\mathrm{H}_{2} \mathrm{SO}_{4}$ were added into a test tube containing $5 \mathrm{ml}$ crude extract. In the lower chloroform layer, the red colour appeared that indicated the presence of steroids.

\section{Design of animal experiment}

A total of 60 cockerels were purchased and allowed to acclimatize in the animal house of Chemistry/Biochemistry department of Alex Ekwueme Federal University, Ebony State, Nigeria for two weeks. Thereafter, they were classified into 12 groups (designated as T1....T12) of 5 cockerels each, where T2, T3 and T4 received 100, 200 and $400 \mathrm{mg} / \mathrm{kg}$ body weight $W$. lateritia leaf decoction, respectively. Anemia was induced in groups T5, T6, T7, T8, T9, T10, T11and T12 by administrating $10 \mathrm{mg} / \mathrm{kg}$ body weight $\mathrm{PHZ}$ on the cockerels for 3 consecutive days; after that T5, T6 and T7 received 100,200 and $400 \mathrm{mg} / \mathrm{kg}$ body weight $W$. lateritia leaf decoction, respectively; T8, T9 and T10 were administered 100,200 and $400 \mathrm{mg} / \mathrm{kg}$ body weight vitali supplement, respectively while $\mathrm{T} 1, \mathrm{~T} 11$ and $\mathrm{T} 12$ were the normal control (distilled water), negative control (not treated) and baseline control (sacrificed on the $3^{\text {rd }}$ day after the manifestation of anemia), respectively. The birds were fed ad libitum and treatment lasted for 30 days.

\section{Induction of Anemia}

Anemia was induced in the groups, T5......T12 by the injection of $10 \mathrm{mg} / \mathrm{kg}$ body weight Phenylhydrazine for three consecutive days, after which the group T12 (baseline control) was sacrificed. Blood was collected through the ocular puncture and biochemical analyses carried out to determine the baseline values of the parameters following the induction of anemia. 
Clinical signs observed upon induction of anemia were: closing of the eyes, weakness and loss of weight and itching of the eyes.

\section{Collection of blood}

After 30 days of treatment, the final weights of the birds were taken before they were sacrificed. Blood sample was collected using a syringe and dispensed as follows: A part into EDTA sample bottle, a fluoride sample bottle and the remaining sample dispensed into a test tube (this was centrifuged to get the serum for the electrolyte analysis).

\section{Biochemical analysis Blood glucose test}

The test was carried using the glucometer method.

\section{Determination of electrolytes}

The serum electrolytes were determined in Orient laboratories, Abakaliki using a piccolo express (chemistry analyzer) automated machine.

\section{Determination of hematological parameters}

Hematological parameters were determined in Orient laboratories, Abakaliki, using Hematology Automated Analyzer, Sysmex NE-8000 model (Toa Medical Electronics Co., Ltd., Kobe, Japan).

\section{Statistical analysis}

Data were analyzed using the statistical package for social science (version17.0). Mean differences measured using one-way analysis of variance (ANOVA). The results expressed as mean \pm standard deviation and differences were considered statistically significant at $(p<0.05)$.

\section{RESULTS AND DISCUSSION}

Table 1 showed that the Whitfieldia lateritia leaf decoction contained an appreciable amount of the following phytochemicals: flavonoids, saponins, tannins cardiac glycosides and steroid. This observation is in line with the work of Aja et al., (2016) who had observed similar phytochemicals in ethanol extract of Whitfieldia lateritia leaf. These bioactive compounds are biochemically active in many respects; eliciting different arrays of biochemical activities (enzyme activation/inactivation, antioxidant activities etc.). Flavonoids have been reported to possess antibacterial property as they can associate with soluble proteins and bacterial cell walls (Doss et al., 2011). They also have antioxidant property as they inhibit oxidative stress by mitigation of the generation of free radicals, exhibit antiinflammatory and anti-cancerous activity (Liu et al., 2008; Alsabri et al., 2013). Flavonoids protect against ultraviolet radiation, pathogens and pests. Saponins have antimicrobial activity (Rohit et al., 2012); interfere with the replication of cell DNA thereby preventing the multiplication of cancer cells (Rohit et al., 2012). Tannins have antimicrobial, antidiarrheal, anti-inflammatory and antioxidant activities. Cardiac glycosides are used for the treatment of cardiac failure. Steroids are precursors of sex hormones (Ajiboye, 2013).
Fig 1 variations in weight gain of anemic cockerels treated with $W$. lateritia leaf decoction and vitali supplement. Weight variations in animals stem from combinatorial factors ranging from impaired feed intake and utilization as well as possible alteration of hormones responsible for animal growth and development. The actions that can produce these effects are increased salivary gland secretion, stimulation of mucus secretion in the stomach and intestine thus, improving nutrient status (Costa et al., 2018).

Fig 2 variations in blood glucose concentration of cockerels treated with of $W$. lateritia leaf decoction and vitali supplement. The blood glucose concentration in the test groups relatively compared with the normal control but was significantly higher $(P<0.05)$ than the negative control $(T 11)$ and baseline control (T12). The observed decrease of the blood glucose in the negative control (T11) and baseline control (T12) suggest that upon the induction of anemia, there was a possible decrease in feed intake as well as metabolic alterations in the cockerels or perturbation of the glucose metabolizing system, such as impaired insulin release or function. However, normal glucose level was restored in the anemic groups while alteration of blood glucose did not occur in the non-anemic groups, suggesting that the extract did not alter glucose metabolism and also could have contributed in protecting the membrane integrity of the pancreas maintaining insulin release thus, increasing glucose absorption by muscle and fat tissues and prevention of glucose production from liver cells (Mangoyi et al., 2017, Kooti et al., 2016). Decrease blood glucose as seen in T4 could occur as a result of inhibition of glucose absorption from the intestine, increase in glucose transport from the blood into the cell (Mangoyi et al., 2017).

Table 2. variations of blood parameters in phenylhydrazineinduced anemic cockerels. The white blood cells, monocytes and neutrocytes were decreased $(p<0.05)$ in the negative and baseline control when compared with the anemic and non-anemic test groups and the normal control. The red blood cells and the hemoglobin were increased significantly $(p<0.05)$ in the test groups when compared with the normal control and the baseline control except the negative control which was significantly increased $(P<0.05)$. The packed cell volume was increased in the test groups than the baseline control but lower than the negative control. The platelets levels were significantly $(P<0.05)$ increased in the baseline control than the anemic and the non-anemic groups (Table 2).

Table 1: Phytochemical constituents of $W$. lateritia leaf decoction.

\begin{tabular}{lc}
\hline Phytochemicals & Remarks \\
\hline Alkaloids & - \\
Flavonoids & + \\
Saponins & + \\
Tannins & + \\
Cardiac glycosides & + \\
Steroids & + \\
\hline
\end{tabular}

+ = Present, - = Absent. 


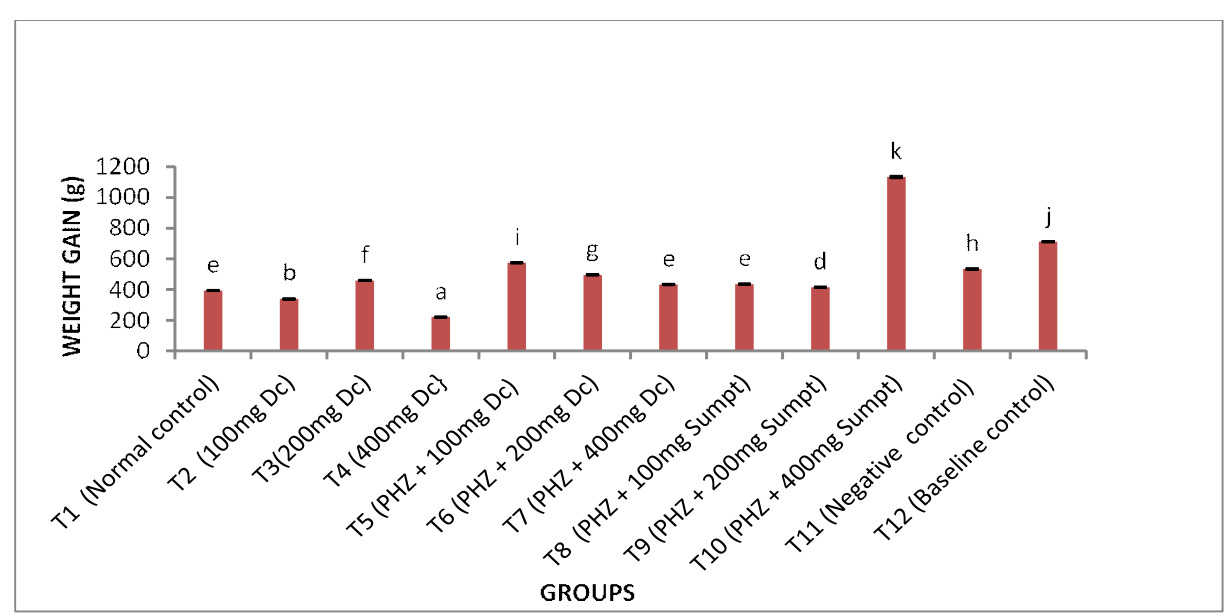

Fig 1: Variations in weight gain of anemic cockerels treated with $W$. lateritia leaf decoction and vitali supplement. Mean $\pm S D$, bars with similar superscripts are not significantly different $(P>0.05) n=5$

Dc- decoction, sumpt - vitali supplement, PHZ- phenylhydraxine.

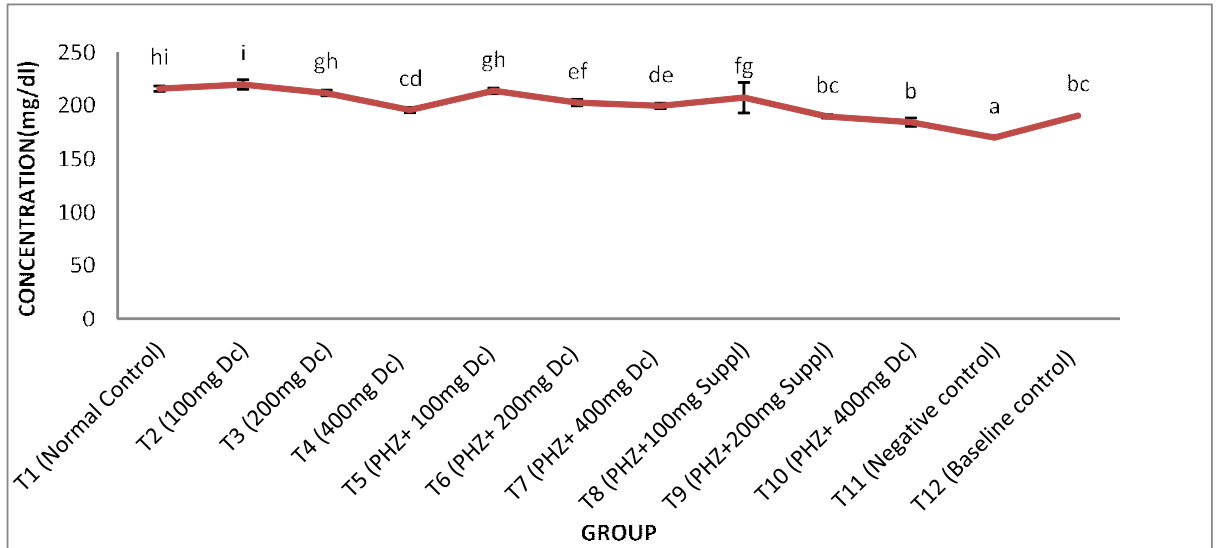

Fig 2: Variations in blood glucose concentration of cockerels treated with of $W$. lateritia leaf decoction and vitali supplement. Mean $\pm S D$, values with similar superscripts are not significantly different $(P>0.05) ; n=5$.

Dc- decoction, suppl - vitali supplement, PHZ- phenylhydraxine.

The white blood cells, monocytes and neutrocytes which were decreased in the negative and baseline control where restored in the treatment groups indicating positive bioactivities of the plant components and ingredients in the vitali supplements. The production WBC is regulated by hematopoietic regulatory elements. Granulocytes-macrophage colony stimulation factor, interleukins (IL-2, IL-4 and IL-5) regulated proliferation, differentiation and maturation of the committed stem cells responsible for the production of WBCs (Jorum et al., 2016). Decrease in WBC counts can be as a result of viral infections, medications like antibiotics, inflammatory cells, malnutrition and vitamin deficiencies (Lewicki et al., 2014). RBC was increased $(p<0.05)$ in the test groups when compared with the normal control and baseline control. The observed decrease in the baseline control could be due to the toxicity of the phenylhydrazine by the involvement of by-products (anyl and hydroxyl) radicals that it generates (Nku-Ekpang et al., 2015). The observed increase in the red blood cells and hemoglobin could be due to phytochemical constituents in the decoction and specific of minerals and vitamins in the supplement. Hematopoietic factors that have direct influence on the production of blood in bone marrow (Nku-Ekpang et al., 2015). The bio-components of the plant leaves could have (1) increased red blood cells counts by inhibition of lipid peroxidation [An indicator of oxidative stress (Prateek et al., 2021)] of the red blood cell membrane lipids (2) stimulated erythropoiesis, possibly, by increasing erythropoietin (ALJarah et al., 2017). The packed cell volume (PCV) of the test groups were significantly altered $(P<0.05)$ when compared to the normal control. A decreased $P C V$ generally connotes RBCs due to loss from blood destruction or loss and failure of bone marrow production. While increased $P C V$ generally suggests dehydration or an abnormal increase in red blood cell production. The platelets count was significantly $(p<0.05)$ decreased in the anemic and the non-anemic test groups treated with decoction and vitali supplement when compared with the baseline control but 


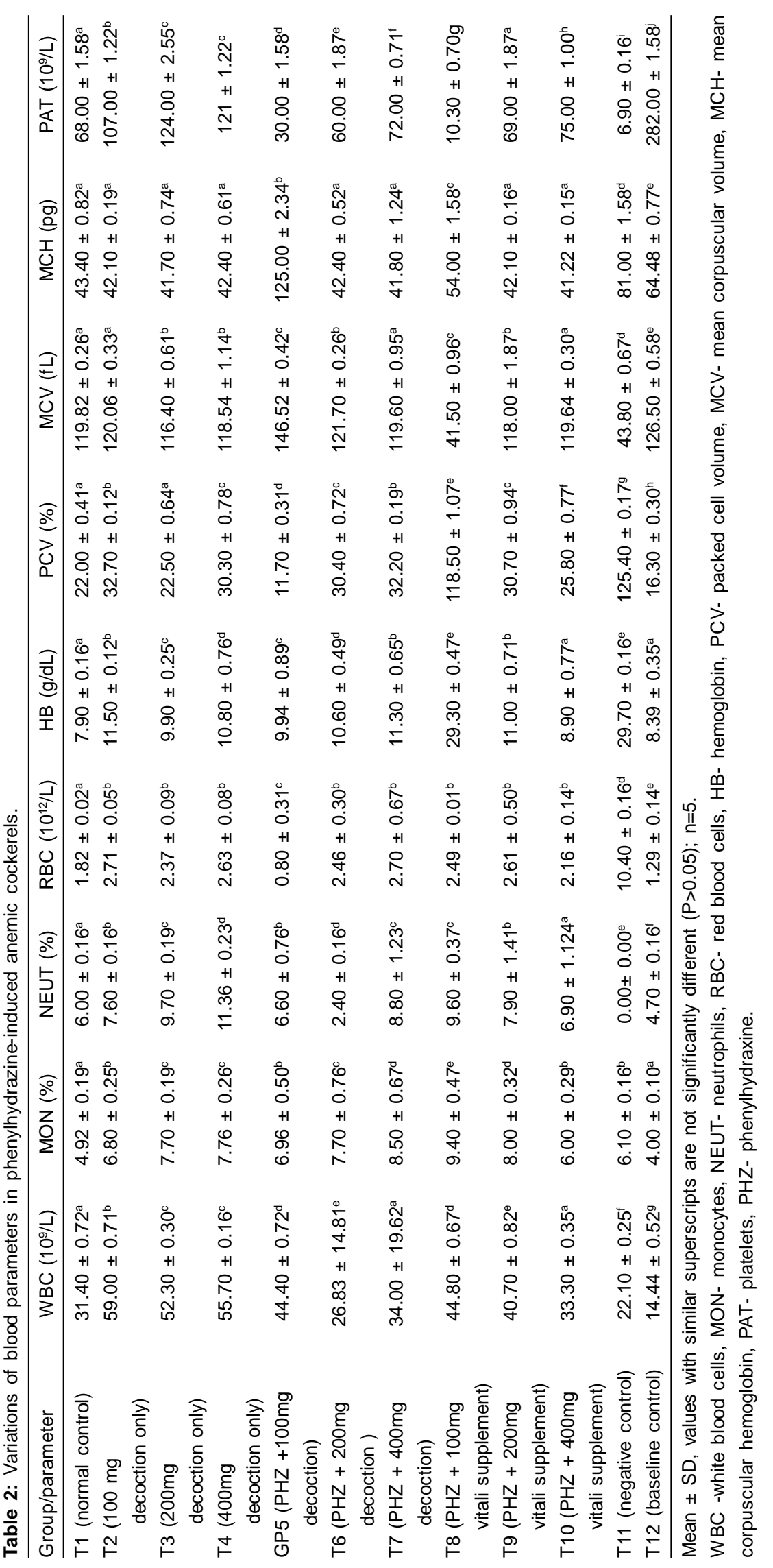


higher than the negative control. Platelets are blood cells involved in blood clothing (Jorum et al., 2016).

Fig 3 variations in calcium and potassium levels of cockerels treated with $W$. lateritia leaf decoction and vitali supplement. The calcium and potassium were significantly increased in the anemic and non-anemic groups treated with decoction as well as the groups treated with vitali supplement (VS) when compared with the baseline control. However, both groups compared well with normal control (Fig 3). Our finding on the serum calcium concentration was in agreement with the work of Florence et al. (2017) who reported an increase on the serum calcium levels of wistar rats fed with aqueous leaf extract of Peperomia pellucid. Although, hypercalcemia could result from overactive parathyroid glands with the manifest kidney diseases such as kidney stone (Craven et al., 2008). The potassium concentrations among the test groups generally compared with the normal control. This is an indication that the treatment was able to restore the potassium decrease due to the induction of anemia with phenylhydrazine (see T12baseline control). The work of Ahmad et al., (2015) had shown that certain plant could increase serum potassium.
Potassium has been shown to have a protective effect against hypertension by attenuating cardiac output through natriuresis (Toshiro et al., 1984). The $\mathrm{Na}^{+}-\mathrm{K}^{+}$ATPase maintains $\mathrm{K}^{+}$balance. Serum $\mathrm{k}^{+}$is controlled by three mechanisms: intake, distribution between intracellular and extracellular fluids and renal excretion. Cellular distribution is affected by insulin and beta-adrenergic receptors that stimulate the activation of $\mathrm{Na}^{+} / \mathrm{K}^{+}$ATPase. Adjustments in potassium levels may affect membrane potential and serum $\mathrm{pH}$ (Aronson and Giebish, 2011). Changes in serum potassium result in an inverse change in the serum $\mathrm{pH}$ (Aronson and Giebish, 2011; Alexander et al., 2001).

Fig 4 variations in bicarbonate, sodium and chloride levels of cockerels treated with Whitfieldia lateritia leaf decoction and vitali supplement. There was no significant difference $(P>0.05)$ in the bicarbonate and chloride concentrations between the test groups, normal control and negative control except T4 that was treated with $400 \mathrm{mg}$ decoction only, which decreased significantly $(p<0.05)$. Sodium concentration was significantly decreased in the test groups treated with $200 \mathrm{mg}$ and $400 \mathrm{mg}$ vitali supplement when compared with the normal control, negative control

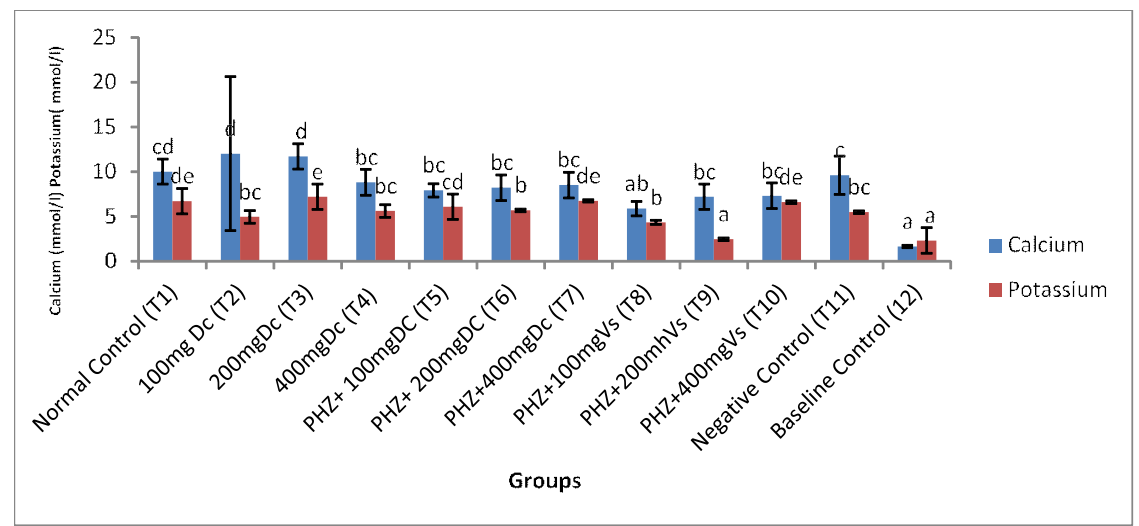

Mean $\pm S D$, bars with similar superscript are not significantly different $(P>0.05)$.

Dc- decoction, Vs - vitali supplement.

Fig 3: Variations in calcium and potassium levels of cockerels treated with $W$. lateritia leaf decoction and vitali supplement.

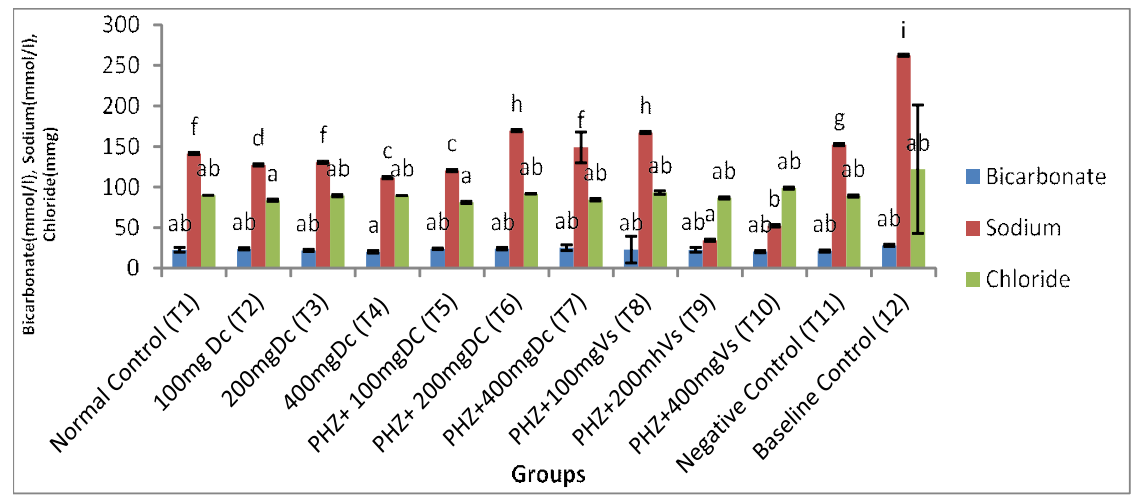

Mean $\pm S D$, bars with similar superscript are not significantly different $(P>0.05)$.

Dc- decoction, Vs - vitali supplement.

Fig 4: Variations in bicarbonate, sodium and chloride levels of cockerels treated with Whitfieldia lateritia leaf decoction and vitali supplement. 
and baseline control. Sodium levels of both the anemic and non-anemic groups were lower $(p<0.05)$ than the negative and baseline control (Fig 4). The lower $\mathrm{H}_{2} \mathrm{CO}_{3}^{-}$reported for $\mathrm{T} 4$ which received $400 \mathrm{mg} / \mathrm{kg}$ bodyweight of decoction might be due to the bioactive components ability to trigger the elevation of the $\mathrm{pH}$ leading to the depletion of $\mathrm{H}_{2} \mathrm{CO}_{3}^{-}$to mitigate the metabolic acidosis. When the bicarbonate levels are decreased or increased, it suggests that the body's acidbase regulation is impaired with the manifest loss or retention of fluid (Ujowundu et al., 2015, Ali Fredrick et al., 2015). Bicarbonate is a primary acid-base buffer in the body and the values recorded in the current study is within the bicarbonate range $(23-29 \mathrm{meq} / \mathrm{L})$ required for the assessment of acid-base balance. Decreased sodium recorded in this study for non-anemic rats of the decoction treated groups might be attributed to the inhibitory action of the extract on anti-diuretic hormone leading to the kidney passing more water directly to the bladder without sodium reabsorption. Hyponatremia may be caused by impaired production of antidiuretic hormones (Ali Fredrick et al., 2015) while increased sodium observed in the baseline control could be due to increased urinary excretion imposed on renal resistance to vasopressin (Palevsky, 1996) attributable to the induction of anemia. The observed non-variation ( $p>0.05)$ in chloride concentration suggest non- interference by the active components of the plant. Chloride is the major extracellular anion and its normal serum concentrations range from 96 to $106 \mathrm{mEq} / \mathrm{L}$ (Gail, 1990) It is important in water distribution, osmotic pressure, anion-cation balance (Augustine, 2015).

\section{CONCLUSION}

The Whitfieldia lateritia leaf decoction showed relative comparative efficacy with the vitali supplement in achieving positive hematopoietic activity including non-alteration of electrolyte and glycemic activities.

\section{ACKNOWLEDGEMENT}

We wish to acknowledge the management of Alex Ekwueme Federal University Ndufu-Alike, Nigeria for given the team unfettered access to the laboratory facilities of the institution.

\section{Ethical clearance}

Ethical clearance was obtained from the University research ethical approval committee.

\section{Funding}

This research was funded by the authors.

\section{Conflict of interest}

The authors declare no conflict of interest.

\section{REFERENCES}

Aja, P.M., Okorie, U.C., Ozougwu, V.E.O., Onye-Mmaghiri, E.A., Agu, K.A., Nweke. O.I. (2016). Phytochemical and gas chromatography-mass spectrometric analyses of Whitfieldia lateritia leaf. African Journal of Basic and Applied Science. 8(1): 41-54.
Ajiboye, B., Emmanuel, I., Genevieve, E. and Sunday, O. (2013). Qualitative and quantitative analysis of phytochemicals in senecio biafrae leaf. International Journal Invention in Pharmaceutical Sciences. 1(5): 428-432.

Ahmad, I.M., Alhassan, M.W., Isa, Y., Zulaihat, G.M., Alhassan, A.S. and Hassan, T.K. (2015). Oral administration of aqueous bark extract of Vitex doniana affects serum electrolytes levels in Albino rats. Journal of Medicine and Medical Research. 1(2). 001-005.

Alexander, V.C., Marina, V.K., Jeffrey W.R., Eric, F., Harriet W., Juleen R.Z. (2001) Insulin-and glucose-induced phosphorylation of the $\mathrm{Na}^{+}, \mathrm{K}^{+}$-adenosine triphosphatase $\alpha$-subunits in rat skeletal muscle. Endocrinology. 142(8): 3474-3482.

Ali Fredrick, U., Ominyi, M.C., Nwankwo, O.V.U., Ibiam, U.A., Ogbanshi, M.E. (2015). Comparative effects of ethanolic extract of gongronema latifolium and piper guineense on blood electrolytes in ethanol exposed wistar rats. Biochemistry and Analytical Biochemistry. 4(3): 179. DOI: 10.4172/ 2161-1009.1000179.

AL-Jarah, G.R. Mohammed, A.S., Jasi, H.A. (2017). Effects of aqueous and methanolic extracts of hibiscus rosasinensis leave on the blood cells of mice in vivo. World J. Exp. Bioscience. 5: 46-49.

Alsabri, S.G., El-Basir, H.M., Rmeli, N.B., Mohamed, S.B., Allafi, A.A., Zetrini, A.A., Salem, A.A., Mohamed, S.S., Gbaj, A., El-Baseir. (2013). Phytochemical screening, antioxidant, antimicrobial and antiproliferative activities study of Arbutus pavarii plant. Journal. Chemical Pharmacology Resource. 5(1): 32-36.

Aronson, P.S. and Gerhard, G. (2011). Effects of pH on potassium: new explanations for old observations. Journal American Society Nephrology. 22(11): 1981-1989.

Augustine Olusegun Olusola (2015). Effect of ethanolic extract of hibiscus sabdariffa and 2, 4-Dinitrophenylhydrazine on kidney function parameters of rats. American Association for Science and Technology Communications. 2(6): 336-343

Awofisoye, O.I., Adeleye, J.O. and Esan, A. (2019). Prevalence and Correlates of anaemia in type 2 diabetes mellitus: A study of the Nigerian outpatient diabetic population. Sahel Medical Journal. 22: 55-63.

Boon, A., Kalalgnan, P.A., Sridhar K., Vairamuthu, S. and Jayathangaraji, M.G. (2019). Hematological and serum biochemical indices of captive royal Bengal Tigers (Panthera tigiris), Arigna Anna Zooogical Park, Vadaloor, Chennai. Indian Journal of Animal Research. 53(12): 1613-1618.

Costa, A.S.H., Costa, P., Alves, S.P., Alfaia, C.M., Prates, J.A.M., Vleck, V., Bessa, R.J.B. (2018). Does growth path influence beef lipid deposition and fatty acid composition? PLoS ONE. 13(8): e0193875.

Craven, B.L., Passman, C. and Assimos, D.G. (2008). Hypercalcemic States associated with nephrolithiasis. Reviews in Urology. 10(3): 218-226.

D'Incalci, M., Steward, W.P. and Escher, A.Y. (2005). Use of cancer chemo preventive phytochemical as anti-neoplastic agents. Lancetonocology. 6(67): 899-904.

Doss, A., Parivuguna, V., Vijaya Santhi, M., Sruthi, S. (2011). Antibacterial and preliminary phytochemical analysis of Medicago sativa L. against some microbial pathogens. Indian Journal Science Technology. 4(5): 550-552. 
Hematopoietic, Electrolyte and Glycemic Activities of Whitfieldia lateritia leaf Decoction and Vitali Supplement on .....

Florence, N.T., Huguette, S.T., Hubert, D.J., Raceline, G.K., Desire, D.D., Pierre, K. and Theophile, D. (2017). Aqueous extract of Peperomia pellucida (L.) HBK accelerates fracture healing in wistar rats. BMC Complementary and Alternative Medicine. 17(1): 188.

Gail, M. (1990). Serum Chloride: In: Clinical Methods. [Kenneth, H. Walker, M.D, W. Dallas Hall, M.D. and J Willis Hurst, MD (Eds)]. https://www.ncbi.nlm.nih.gov/books/NBK309/.

Harbone, J.B.C. (1973). Phytochemical Methods. Chapman and Hall, London. P.279.

Janz, T.G., Roy, L.J. and Scott, D.R. (2013). Anemia in the emergency department: Evaluation and treatment. Emergency Medicine Practice. 15(11): 1-15.

Jorum, O.H., Piero, N.M., Machocho, A.K. (2016). Haematological effects of dichloromethane-methanolic leaf extracts of Carissa edulis (Forssk.) vahl in normal rat models. Journal Hematology Thrombo Disease. 4: 232. http://dx. doi.org/10.4172/2329-8790.1000232.

Kayode, O.O. and Adeolu, O.O. (2012). Anaemia in Developing Countries: Burden and Prospects of Prevention and Control, Anemia, [Dr. Donald Silverberg (Ed.)], ISBN: 978953-51-0138-3, InTech, Available from: http://www. intechopen.com/books/anemia/anaemia-in-developingcountries-burden-andprospects-of-prevention-and-control.

Khan, R.N., Saba, F., Kausar, S.F. and Siddiqui, M.H. (2019). Pattern of electrolyte imbalance in Type 2 diabetes patients: Experience from a tertiary care hospital. Pakistan Journal of Medical Sciences. 35(3): 797-801.

Lewicki, S., Lewicka, A., Kalicki, B., Kłos, A., Bertrandt, J. and Zdanowski, R. (2014). The influence of vitamin B12 supplementation on the level of white blood cells and lymphocytes phenotype in rats fed a low-protein diet. CentralEuropean Journal of Immunology. 39(4): 419-425.

Liu, X., Zhao, M., Wang, J., Yang, B., Jiang, Y. (2008). Antioxidant activity of methanolic extract of emblica fruit (Phyllanthus emblica L.) from six regions in China. Journal Food Composition Analysis. 21(3): 219-228.

Kooti, W., Farokhipour, M., Asadzadeh, Z., Ashtary-Larky, D. and Asadi-Samani, M. (2016). The role of medicinal plants in the treatment of diabetes: A systematic review. Electronic Physician. 8(1): 1832-1842.

Mangoyi, J., Ngcobo, M. and Gomo, E. (2017). Mechanisms of action of traditional herbal medicines used in the management of diabetes mellitus: A review of the literature. African Journal Traditinal Complement Alternative Medicine. 14 (5): 156-165.

Njoku, O.U., Okorie, U.C., Obasi, N.A., Ogwulumba, S.I. and OtuChristian, G. (2015). Proximate and mineral compositions of whitfieldia lateria leaves from Ishiagu-Ivo, Ebonyi State, Nigeria. Journal Biological Chemical Research. 32(1): 77-83.
Nku-Ekpang, O.T., Nwaehujor, C.O., Ofem O.E. and Ezekiel J.I. (2015). "Effect of Moringa oleifera lam. Ethanol leaf extract on hematology in phenylhydrazine-induced anemic albino wistar rats." American Journal of Pharmacological Sciences. 3(3): 67-73.

Okorie, U.C., Obasi, N.A., Aja, P.M., Oje, O., Ogwulumba, S.L. and Njoku, O.U. (2020). Vitamins, amino acids and antinutrient compositions of Whitfieldia lateritia leaves. Journal of Chemical, Biological and Physical Sciences. 10(2): 192202.

Palevsky, P.M., Bhagrath and Greenberg, A., (1996). Hypernatremia in hospitalized patients. Ann. International Medicine. 124: 197- 203.

Parashuramulu, S., Devanaboyina, N.M. and Kishan, K. (2015). Effect of zinc supplementation on haematology and serum biochemical constituents in Murrah buffalo calves. Indian Journal of Animal Research. 49(4): 482.

Prateek, M., Vidhi G., Sharma R.K., Anushri, T. (2021). Alterations in biochemical markers of liver and kidney function and oxidative stress indices on sub-acute exposure of enrofloxacin in albino rats. https://www. arccjournals.com/journal/indian-journal-of-animalresearch/B-4453. DOI: 10.18805/IJAR.B-4453.

Prity, S., Rajendra, K.P., Vinod, K.P., Satya, P.Y., Basant K.B. and Chandra, S.S. (2019). Effect of supplementation of $L$. plantarum and L. casei based probiotic milk powder on hematology, blood biochemistry and lipid profile of Charles Foster rats. Indian Journal of Animal Research. 53: 332-335.

Rajkumar, U., Prince, L.L.L., Santosh Haunshi, Chandan Paswan, Muthukumar, M. (2021). Evaluation of growth, carcass and meat quality of a two-way cross developed for rural poultry farming. Indian Journal of Animal Research. (55): 498-502.

Rohit, S., Thakur, G.S., Sanodiya, B.S., Mukeshwar, P. and Prakash, B. (2012). Saponin: A wonder drug from chlorophytum species. Global Journal of Research on Medicinal Plants and Indigenous Medicine. 1(10): 503-515.

Toshiro fujita, M.D., Hiroshl Noda, M.D. and Katsuyuki Ando, M.D. (1984). Sodium susceptibility and potassium effects in young patients with borderline hypertension. Circulation. Pathophysiology and Natural History. 69(3): 468-476.

Trease, G.E., Evans, W.C. (1987). Pharmacognosy. Bailliare Tindall, London.

Ujowundu, C.O., Kalu, F.N., Nwaoguikpe, R.N., Okechukwu, R.I., Ihejirika, C.E. (2015). The antioxidative potentials of G. latifolium on diesel petroleum induced hepatotoxicity. Journal of Applied Pharmaceutical Science. 2: 90-94.

Upasana, S., Purva, S.D., Susmita, S. and Madhu, M. (2018). Plant extracts as an astounding remedy to anaemia - A review. Annals of Plant Sciences. 7(4): 2166. 